\title{
THE ROLE OF INDUSTRY CLASSIFICATION IN THE ESTIMATION OF RESEARCH AND DEVELOPMENT EXPENDITURES
}

\author{
by
}

\author{
Christian Awuku-Budu ${ }^{1}$ \\ U.S. Bureau of Economic Analysis
}

Carol A. Robbins

U.S. Bureau of Economic Analysis

\begin{abstract}
CES 14-45 November, 2014
The research program of the Center for Economic Studies (CES) produces a wide range of economic analyses to improve the statistical programs of the U.S. Census Bureau. Many of these analyses take the form of CES research papers. The papers have not undergone the review accorded Census Bureau publications and no endorsement should be inferred. Any opinions and conclusions expressed herein are those of the author(s) and do not necessarily represent the views of the U.S. Census Bureau. All results have been reviewed to ensure that no confidential information is disclosed. Republication in whole or part must be cleared with the authors.

To obtain information about the series, see www.census.gov/ces or contact Fariha Kamal, Editor, Discussion Papers, U.S. Census Bureau, Center for Economic Studies 2K132B, 4600 Silver Hill Road, Washington, DC 20233, CES.Papers.List@census.gov.
\end{abstract}




\begin{abstract}
This paper uses data from the National Science Foundation's surveys on business research and development (R\&D) expenditures that have been linked with data from the Census Bureau's Longitudinal Business Database to produce consistent NAICS-based R\&D time-series data based on the main product produced by the firm for 1976 to 2008. The results show that R\&D spending has shifted away from domestic manufacturing industries in recent years. This is due in part to a shift in U.S. payrolls away from manufacturing establishments for R\&D-performing firms. These findings support the notion of an increasingly fragmented production system for R\&D-intensive manufacturing firms, whereby U.S. firms control output and provide intellectual property inputs in the form of $R \& D$, but production takes place outside of the firms' U.S. establishments.
\end{abstract}

Keyword: Business R\&D, industry classification, factoryless goods producers, U.S. manufacturing firms, establishments

\footnotetext{
${ }^{1}$ The authors wish to thank David Byrne, Ian Mead, Guci Ledia, and John Jankowski for valuable comments. We also wish to thank Cheryl Grim for sharing the codes that were used to match firms to establishments. Corresponding author:Christian.awukubudu@bea.gov.
} 


\title{
THE ROLE OF INDUSTRY CLASSIFICATION IN THE ESTIMATION OF RESEARCH AND DEVELOPMENT EXPENDITURES
}

\author{
Christian Awuku-Budu and Carol A. Robbins \\ Analysis and Special Studies Branch, Regional Product Division, BEA
}

The National Science Foundation (NSF)'s annual surveys on business research and development (R\&D) expenditures are the primary federal sources for industry R\&D expenditures in the United States. The business R\&D data sets provide an important window into the growth dynamics of industries that fund and perform R\&D. In addition, the information in the NSF-tabulated data sets is used extensively by government agencies and private enterprises to evaluate the impacts of R\&D expenditures on economic activity. ${ }^{2}$ Despite the relevance and usefulness of these annual R\&D expenditure data sets, these data as collected have been affected by changes in how firms have been classified into industries over the years. $^{3}$

This paper uses data from the NSF's surveys on business R\&D expenditures that have been linked with data from the Census Bureau's Longitudinal Business Database to produce data series with a consistent set of industry classification standards based on the main product produced by the firm for 1976 to 2008. The adjustment to industry classifications is done on both a broad and more targeted basis to analyze how much focus needs to be placed on adjustments to firms initially classified into the management of companies, scientific R\&D services, and wholesale trade industries.

We then evaluate our estimates by comparing them to estimates of R\&D expenditures obtained using the line of business information reported in the 2008 Business Research and Development and Innovation Survey (BRDIS) data. Our estimates are comparable to the BRDIS tabulation for computer and electronic product manufacturing. Relative to BRDIS for 2008, we somewhat underestimate R\&D expenditures for chemical manufacturing and overestimate R\&D expenditures for other manufacturing industries. Our main contributions to the literature are a consistent methodology and NAICS-based business-performed R\&D data for 1976 to 2008.

Our results support earlier work done at BEA during the development of its R\&D satellite accounts to address changes in how firms have been classified into industries in the NSF data. This paper differs from this previous work by using micro data and the same classification technique over the entire period rather than adjusting more aggregate data with special tabulations from the NSF and the U.S. Census Bureau.

\footnotetext{
${ }^{2}$ For example, the Bureau of Economic Analysis (BEA) incorporated R\&D expenditures as investment in the National Income and Products Accounts (NIPAs) in July of 2013, which increased the measured level of GDP back to 1929. The NSF R\&D expenditures are the main source of data for the change in BEA's measures of industry R\&D investment.

${ }^{3}$ These adjustments to the classification methodology rose from efforts to meet the needs of data users as the structure of U.S. economic activity shifted and the Federal Statistical System switched from the Standard Industrial Classification (SIC) to the North American Industrial Classification (NAICS).
} 
The results of our paper show that R\&D spending has more recently shifted away from domestic manufacturing industries. This is due in part to a shift in U.S. payrolls away from manufacturing establishments for R\&D-performing firms, and also a shift upward in the proportion of firm-level payrolls for R\&D-performing firms that are engaged in trade and other services activities. These findings support the notion of an increasingly fragmented production system for R\&D-intensive manufacturing firms, whereby U.S. firms control output and provide intellectual property inputs in the form of R\&D, but production takes place outside of the firms' U.S. establishments.

\section{Background}

This section provides background on industry classification methods, those historically used by the NSF, and their effect on resulting tabulations of data.

\section{Industry Classification}

Industry classification systems group economic data in order to enable cross-sectional and, frequently, time-series analysis. These systems can be divided into two basic categories, a demand-oriented system that groups similarly purposed commodities and services, and a production-oriented industry classification system that groups producing units with similar production technologies. ${ }^{4}$ When the classification is done consistently across federal statistical agencies, different data sources can be linked together. This linking provides insights into the structure of the economy that would otherwise not be discernable.

The North American Industry Classification System (NAICS) was introduced into the Federal Statistical System in 1997 to replace the Standard Industrial Classification (SIC) system, which was based on the principal product produced. ${ }^{5}$ NAICS is based on the economic concept of similarity of production activities at the level of establishments. The NAICS Manual notes that primary activity should be determined for each establishment based on the "relative share of current production costs and capital investment" (2002 NAICS Manual, page 22). ${ }^{6}$ Additionally, given its expanded coverage of emerging industries, NAICS captures the growing importance of service- and technology-producing industries.

For multi-unit firms with diverse production activities, a NAICS framework can be implemented in ways that lead to different results. To our knowledge, there is no consensus on a single method to classify multi-unit firms into a primary industry based on production activity. A 2012 report prepared for the U.S. Census Bureau by Robert Parker reviews five alternative methods that are used within the Federal Statistical System to classify enterprises, and concludes that the methods differ in how

\footnotetext{
${ }^{4}$ Economic Classification Policy Committee (ECPC), 1993.

${ }^{5}$ The SIC assigned operating establishments to industries on the basis of primary activity, which was defined as "determined by its principal product or group of products produced or distributed, or services rendered" (1987 Standard Industrial Classification Handbook, pg. 15).

${ }^{6}$ In practice, this grouping is done at the Census Bureau based on the producing units' revenue or value of shipments to identify primary business activity (http://www.census.gov/eos/www/naics/faqs/faqs.html\#q4).
} 
industries are identified, where overseas operations are included, level of detail, and whether company or establishment information is used to identify industry classification (Parker, 2012).

One general solution to the industry classification issue for multi-unit firms is a multiple stage "hierarchical" approach. In the first stage, the firm is assigned to a major sector based on highest share of payroll, receipts, or some other measure. Within that major sector, the firm is then assigned to a subsector, based on the highest share across the sub-sectors within the major sector. In a third stage of the process, the firm is then assigned to a detailed industry within the sub-sector, based on the highest share across the detailed industries with the sub-sector. A feature of this approach is that the firm is assigned first to the most appropriate major group, even if the firm is involved in diverse activities. This method is used for multinational corporation data, assigning firms to one industry by a three stage process. In this case, sales receipts are used (BEA, 2013).

For other statistical data, payroll information is often the data item that is defined and reported the same way across economic sectors. The cycle of the 2012 Economic Census includes a revived set of enterprise statistics informed by Parker's work. The classification of enterprises for these statistics is based on an aggregation of domestic establishment payroll data. The method is described as follows (Parker, 2012):

For each enterprise, the classification methodology starts by excluding nonoperating establishments - establishments classified as manufacturers' sales branches and offices, central administrative offices (NAICS 551114), and "auxiliaries." From the remaining establishments, a primary NAICS sector is selected. If the primary sector is outside the scope of the 2007 Economic Census, the records of the establishments in these sectors are deleted and a primary in-scope sector is selected based on payroll. The primary Enterprise Classification System category is the category in that sector with the largest aggregate payroll.

This hierarchical approach can treat establishments within firms consistently, but can also obscure valuable information about the firm. While NAICS is focused on the production process at the establishment level, a key distinction for enterprises is an understanding of ownership characteristics and control of shared inputs, including intangible ones. Survey data collected at the firm level provide ownership and control information not generally available at the establishment level. Additionally, focusing on the domestic establishments of the firm can be unrepresentative of globally-active firms.

\section{Classification of R\&D Expenditures}

For R\&D expenditures, the Survey of Industrial Research and Development (SIRD) used the SIC system from 1953 until 1999, when NAICS was adopted. Firms were classified to industries based on the industry code within the company that had the greatest number of employees. The end result was understood by data users to be based on the market-based product or service sold by the R\&Dperforming firm (Shackelford, 2008). The paragraphs below describe the four major changes in NSF's classification procedure.

Freezing of firms. In the early 1980s, hand-editing of firms was developed in response to the observation that some large consolidated firms with manufacturing establishments shifted over time from manufacturing to wholesale trade without any change in the product produced by the firm. NSF 
staff developed a procedure to maintain the classification of the primary product that the firms sold in the market by continuing to classify these R\&D expenditures in the manufacturing industry. This procedure was known as "freezing" of firms.

This "freezing" of firms based on analyst's knowledge about the R\&D performers continued until 1992. In this year, according to Shackelford (2008), NSF stopped freezing many firms' industry codes. As a result, firms that were formerly classified in manufacturing were increasingly assigned to the wholesale trade sector and other private services-producing industries.

NAICS. With the introduction of NAICS in 1999 to NSF's industry tabulations, firms continued to be assigned to industries based on the highest payroll shares. ${ }^{7}$ However, NAICS changed the way that auxiliary units were treated within firms, assigning them to separate service industries. R\&D is performed in at least two types of auxiliary units, R\&D support establishments and company headquarters, which would not align with the market-based product or service sold by the firm. Classifying R\&D here would have changed the way that users understood the R\&D statistics from the survey. NSF's response was to exclude auxiliary units from the process of determining industry classification for multi-unit firms.

Following the introduction of NAICS, the industry group "Trade" emerged as one of the largest performers of domestic R\&D activity in the early 2000s. For NSF, this development "ran counter to analyst understanding of corporate R\&D and did not accurately reflect the industry-structure of R\&D in the U.S. economy" (Shackelford, 2008). ${ }^{8}$ What followed at NSF was a more extensive investigation of firm-level data from the 2004 survey. This revealed that some large R\&D-performing firms had their largest domestic payroll shares in trade or other auxiliary activities, rather than in manufacturing of the final market-based product.

Wholesale trade and service adjustment. NSF analysts responded by setting up a system of rulebased adjustments that reclassified R\&D activity back to the final product industry. In practice, the most significant effect was to reclassify R\&D expenditures out of wholesale trade and into three manufacturing industries: pharmaceutical and medicine (NAICS 3254), semiconductor and other electronic component (NAICS 3344), and communications equipment (NAICS 3342). This practice continued from 2004 until 2007, the last survey year for the SIRD.

\section{Business R\&D and Innovation Survey (BRDIS). The redesigned BRDIS in 2008 was a major} expansion of the NSF business R\&D survey. It now includes greater detail on the nature of the R\&D activity within the firm, the firm's geographic location, and its financing. In addition to the variables in the SIRD data sets, BRDIS collects information on firms' domestic R\&D performance by business lines, allowing firms to report R\&D related to multiple lines of business. By collecting data by line of business, the BRDIS effectively provides R\&D expenditures based on the kinds of products that the R\&D activity is

\footnotetext{
${ }^{7}$ Shackelford (2008) notes various exclusions and exceptions, along with the hand-editing.

${ }^{8}$ One reason why this development was hard to understand was that wholesale and retail trade industries under NAICS are defined as engaged in activities that are not transformative. Any services performed are "incidental to the sale of merchandise" (2002 NAICS Manual pages 507 and 551). Classifying R\&D into the Trade category appears to explain little about the economic activity of the firm.
} 
used to create. This change allowed firms to report multiple lines of business, account for both domestic and international R\&D activity, resulting in an industry classification that returned conceptually to the final product classification.

The major changes to NSF's industry classification methodology between 1980 and the introduction of BRDIS for the 2008 survey year are summarized in table 1 . These major changes include discontinuing the "freezing" of firms' industry codes starting from 1992, switching from SIC to NAICS in the tabulated results in 1999, and instituting the wholesale trade adjustments from 2004 forward.

\begin{tabular}{|c|c|l|}
\hline \multicolumn{3}{|c|}{ Table 1: Significant Changes in the Method for Assigning R\&D-Performing Firms to Industries } \\
\hline A & 1981- & $\begin{array}{l}\text { Hierarchical payroll method was introduced. NSF also manually reviewed firms' } \\
\text { industry codes, and occasionally adjusted some of them to ensure they were } \\
\text { consistent with the industry codes the firms were assigned to in the past. This } \\
\text { approach was described by Shackelford (2008) as "freezing" the industry } \\
\text { classification of firms. }\end{array}$ \\
\hline B & $1992-$ & NSF discontinued the freezing of firms' industry codes. \\
\hline C & $1999-$ & $\begin{array}{l}\text { NSF began tabulation of R\&D expenditure data on NAICS basis. Prior years R\&D } \\
\text { expenditure data were tabulated on SIC basis. }\end{array}$ \\
\hline D & $2004-$ & $\begin{array}{l}\text { NSF manually reviewed and adjusted the industry codes for some of the firms } \\
\text { that were assigned to wholesale trade and some services-producing industries. }\end{array}$ \\
\hline E & $2008-$ & $\begin{array}{l}\text { NSF tabulated industry R\&D expenditure data using line of business information } \\
\text { reported in the BRDIS data sets. }\end{array}$ \\
\hline
\end{tabular}

Source: Brandon Shackelford (2008).

In retrospect, the shift from SIC to NAICS shed light on a structural shift for many R\&Dperforming firms in the domestic economy away from manufacturing payrolls. NSF responded to this change with an explicit return to the concept of final product as the classification system that best suited its data users.

\section{Effects of Changes in R\&D Classification}

Figures $1 a, 1 b$, and $1 c$ show the patterns when the R\&D data are viewed as a time series for the servicesproducing industry group, the manufacturing industry group, and the wholesale trade industry. The charts show the year-to-year changes in R\&D expenditures relative to initial R\&D expenditures based on NSF's classification of the firms. ${ }^{9}$

Figure 1a shows the trend in funds for R\&D performance for the services-producing industry group. The red line shows the year-to-year changes in company and other-funded R\&D performance and the blue line shows federally-funded R\&D performance. For services, the series appears to shift around 1992. This timing corresponds with the "unfreezing" of industry codes in the classification methodology described earlier (B in table 1).

\footnotetext{
${ }^{9}$ We regress R\&D expenditures for industry group $j$ in year $t$ as the dependent variable on the interaction terms of industry group $j$ 's initial R\&D expenditures and year dummies. These time-varying coefficients on the interaction terms measure the year-to-year change in R\&D expenditure for industry group $j$ relative to industry group $j$ 's initial R\&D expenditures.
} 
Figure $1 b$ shows the year-to-year change in R\&D expenditures relative to $1972 R \& D$ expenditures for the manufacturing industry group. The red and the blue lines break down the total R\&D performance of manufacturing firms into company-funded (solid red) R\&D performance and federally-funded (blue) R\&D performance, respectively. For the company-funded R\&D performance, there was an overall gradual increase from early 1970s to 2002 with small intermittent declines. However, the chart also shows what appears to be a change in the time series after 2003, with timing that corresponds to the wholesale trade and service industry adjustment described above (D in table 1).

The next figure, 1c, shows the year-to-year change in the company-funded R\&D performance for the wholesale trade industry from 1972 to 2008. From 1972 to 1992, during the time when firms that were originally in manufacturing were frozen there, we observe almost no change in the companyfunded R\&D performance for firms classified in wholesale trade. In the early 1990s, concurrent with the "unfreezing" of the classification of firms with manufacturing establishments ( $B$ in table 1 ), we see a sharp increase in the company-funded R\&D performance. Figure $1 \mathrm{c}$ also shows the sharp decline in 2004, corresponding to the adoption of the adjustments for wholesale trade and service industries ( $D$ in table 1).

\section{Methodology}

This section discusses the three main micro-data sets and the methodology to create a consistent set of R\&D time-series data by industry for 1976 to 2008.

Data. The primary data sets that we use are firm-level SIRD and BRDIS R\&D micro-data sets and establishment-level data from the Longitudinal Business database (LBD). ${ }^{10}$ We use R\&D data sets from the SIRD from 1976 to 2007 and from BRDIS for 2008. The variables we use from these data sets are a unique firm identifier, the firm's industry classification, domestic R\&D performance funded by federal government agencies, and domestic R\&D performance funded by industry and others. ${ }^{11}$ The R\&D data from SIRD and BRDIS are linked to establishment-level data through the LBD. The LBD contains annual information on establishments' annual payroll, employment, operational status, industry classification, state, zip code where the establishments are located, and a unique establishment identifier. There are over 5 million domestic non-farm private business establishments in the LBD in any given year. ${ }^{12}$ We also use data from the quinquennial economic censuses to recode some establishments in the LBD from SIC basis to NAICS basis.

Methodology. Our methodology creates R\&D expenditures by year and industry in two different ways.

\footnotetext{
${ }^{10}$ These data were accessed at the secure Census Bureau Headquarters Research Data Center under confidentiality agreements with respect to the scope of results that can be removed from the Research Data Center and reported.

${ }^{11}$ Others include state and local government, nonprofit institutions, and universities and colleges. Others also include foreign entities that purchased R\&D from the domestic R\&D-producing firms. However, the total amount of this R\&D is relatively small.

${ }^{12}$ The LBD was constructed using establishment and firm information from the Business Register. The establishments industry classification for SIC industry codes are available for all establishments prior to 1999 and are only available for some establishments after 1999. The NAICS industry codes are available for all firms after 2002, and are only available for some firms prior to 2002. The NAICS codes before 1997 have been assigned by researchers at the Census Bureau's Center for Economic Studies.
} 
The first way is based on a hierarchical method using payroll shares and the second is based on the primary product, using the manufacturing establishments in the firm's U.S. operations. In practice, the difference between our method and what was done in the SIRD series is that we use the same procedure for each year.

There are four steps in the creation of a set of industry time series for firms: 1) match firms in the SIRD to their constituent establishments in the LBD; 2) recode establishments in the LBD from SIC basis to NAICS basis; 3 ) use the hierarchical payroll method to assign firms to industries for a consistent NAICS assignment; and 4) reassign selected firms to manufacturing that were assigned to wholesale trade and other services industries.

Merging the firms. Our approach is similar to the approaches used by previous studies that have merged firms in the SIRD data sets to establishment-level datasets (Lichtenberg and Seigel, 1991; Adams and Peck, 1994; Adams and Jaffe, 1996; and Foster and Grim, 2010). We start by merging the firms in the SIRD data sets to the establishments in LBD using a unique census firm identifier in the SIRD and in the LBD data sets. ${ }^{13}$

Following the method of Foster and Grim (2010), we use the 5-year window of the LBD in our matching of firms to establishments, which, on average, led to about a 99 percent matching rate for multi-unit firms and about a 95 percent matching rate for single-unit firms.

SIC to NAICS. The next step is to develop a NAICS-based time series at the firm level for years prior to 1999, when the data were collected on a SIC basis. Some of the establishments in the LBD have already been assigned NAICS industry codes by researchers at CES as part of an ongoing project. Our method for assigning the remainder to NAICS codes follows Bayard and Klimek (2003) and Klimek and Merrell (2003).

We use exact matching where possible, and probabilistic matching for the remainder. Specifically, for establishments that have no NAICS codes assigned in the LBD, we assign these establishments to NAICS codes of the establishment in the closest year for which a NAICS code is not missing. For the rest, we use the 1997 SIC-to-NAICS bridge table to assign each establishment to a NAICS industry when there is an exact match between the establishment's SIC code and a NAICS code in the bridge table. We also match establishments' ID in LBD to their ID in the Census of Manufactures or Census of Service industries and assign the NAICS code found in the censuses. The rest are assigned using a statistical matching procedure based on establishment payroll and other characteristics.

Payroll method. Next, we assign firms to 4-digit industry codes using the hierarchical payroll method for each year of data. We first assign the firm to one of the major economic sectors, then to the 2-digit industry within the largest economic sector. We then assign the firm to 3-digit industry within the twodigit and so on. When this step is concluded we have our consistent payroll-based series.

\footnotetext{
${ }^{13}$ For more information on firm identifiers in the SIRD and establishment identifiers in the LBD, see Adams and Peck (1994) and Jarmin and Miranda (2002).
} 
Final step. In the last step, we attempt to replicate the "freezing of firms" in a consistent manner. In effect, we are reassigning a subset of firms from services and trade industries to manufacturing. A relatively broad adjustment reassigns to manufacturing the R\&D performed by firms that switch from manufacturing to services and trade industries using the payroll method.

The reassignment works as follows. If the LBD assigned the firm to manufacturing in the past, but in a subsequent year there are manufacturing establishments and the payroll method also assigns the firm to a nonmanufacturing industry, we change the firm industry code to the manufacturing industry with the largest payroll share. In addition, if the firm is assigned to a nonmanufacturing industry in a given year but the firm has establishments in manufacturing sector in the LBD, then we assign the firm to the manufacturing industry with the largest payroll share.

To better understand the scope of NSF's historical adjustments, we also create an alternative reassignment. This more targeted adjustment reassigns to manufacturing the R\&D performed by firms that switch from manufacturing to one of three sectors: wholesale trade (NAICS 42), scientific R\&D services (NAICS 5417), and management of companies and enterprises (NAICS 551).

\section{Main Results}

This section presents the results on the reclassifications of industries using the broad-based matching. Afterwards, conclusions are drawn related to evidence of the importance of factoryless goods production as it relates to industry classification.

\section{Matching Results}

Figure 2a compares two versions of company-funded R\&D performance from 1976 to 2008 . The payroll method is the hierarchical method described earlier implemented with payrolls. The service-and-tradeadjusted series uses the alternative approach that is intended to reflect primary product. Prior to 1992, the estimates in the service-and-trade-adjusted series are slightly higher than the corresponding estimates in the payroll-method series. However, from 1992 to 2001 the differences between the two series become gradually larger. The largest differences are observed from 2002 forward. For example, the difference between the estimates of company and other funds for R\&D performance is about 26 billion dollars for 2003 and 27 billion dollars for 2007.

Figure $2 \mathrm{~b}$ shows the broad-adjusted series and the payroll-method series for federal funds for R\&D performance by manufacturing firms for years 1976-2008. Prior to 1985, the broad-adjusted series are slightly higher than the payroll-method series. For the remaining years, the broad-adjusted series are moderately higher than the payroll-method series. The largest differences between the two series are observed for the 1986-1996 and the 2005-2007 periods. The smaller differences between the two series suggest that firms performing R\&D with federal money were less affected by industry reclassification caused by shifting payrolls at the establishment level.

Table 2a shows the broad-adjustment impact on the number of firms and the R\&D expenditures reassigned from services and trade industries to manufacturing for the years 1986-2008. On average, 28 percent of firms assigned to services and trade industries using the payroll method and the broad 
adjustment were reassigned to industries in manufacturing. Table $2 \mathrm{a}$ also shows that, on average, twothirds (67 percent) of company and other funds for R\&D that would be considered to be services and trade R\&D using the payroll method are classified as manufacturing R\&D when we attempt to classify the R\&D based on the primary product.

Table 2a further shows that R\&D grew substantially in firms that did not have manufacturing establishments. Although the number of firms that were assigned to services and trade using the payroll method increased from 196 in 1986 to 1,337 in 2008, the share of firms that were reassigned decreased from 51 percent in 1986 to 15 percent in 2008. Similarly, while the level of company and other R\&D funds assigned to the services and trade industries using the payroll method increased from 7.6 billion dollars in 1986 to 53.3 billion dollars in 2008, the share of funds reassigned to manufacturing decreased from 89 percent in 1986 to 56 percent in 2008.

However, a relatively small number of firms account for a large proportion of the service-andtrade adjustment in recent years. For example, in 2008 about 15 percent of the firms reassigned from services and trade to manufacturing industries accounted for more than 56 percent of the R\&D originally assigned to services and trade. These are large R\&D-intensive firms with increasing payroll share in the services and trade industries.

Table $2 \mathrm{~b}$ presents data that take a closer look at the industries within manufacturing that are most affected. Across all years, half of the firms are in only two industries, computer and electronic product manufacturing and chemical manufacturing. On average, 133 firms were moved to manufacturing industries from services and trade industries, of which 29 percent were reassigned to computer and electronic product manufacturing, 22 percent to chemical manufacturing, and 49 percent to other manufacturing industries. In addition, about 18 billion dollars of company and other R\&D were moved to manufacturing industries, of which, 72 percent of the R\&D expenditures were moved to computer and electronic product manufacturing, 21 percent to chemical manufacturing, and 6 percent to other manufacturing industries.

Over time, the R\&D expenditures that were reassigned for firms with chemical manufacturing establishments increased relative to firms with computer and electronic product manufacturing establishments. The share of company and other R\&D moved to manufacturing for computer and electronic product manufacturing decreased from 90 percent in 1986 to 35 percent in 2008. In contrast, the share of R\&D moved to manufacturing that was allocated to chemical manufacturing increased from 5 percent in 1986 to 54 percent in 2008 . The share that goes to other manufacturing industries increased marginally from 5 percent in 1986 to 11 percent in 2008.

Figure 3a shows the service-and-trade-adjusted series and the payroll-method series of company and other funds for R\&D performance by computer and electronic product manufacturing firms. This industry includes the semiconductor and other electronic component manufacturing. As shown, the differences between the service-and-trade-adjusted series and payroll-method series for the years prior to 2001 are large. Between 2001 and 2007, the service-and-trade-adjusted series become significantly higher than the payroll-method series. For instance, in 2002, the estimate in the serviceand-trade-adjusted series is about 7 billion dollars higher than the estimate in the payroll-method series, whereas in 2007 it is about 13 billion dollars higher. From 2003 to 2006, the service-and-trade-adjusted 
estimates again become moderately higher than the payroll-method series. The service-and-tradeadjusted series are generally higher than the payroll-method series because large R\&D-intensive firms were moved from the services-producing industries, particularly from scientific $R \& D$ and related services, to computer and electronic product manufacturing industries. Semiconductor R\&D is a large part of computer manufacturing R\&D and our results are consistent with the results for semi-conductors manufacturing obtained by Bayard, Byrne, and Smith (2013).

Figure $3 \mathrm{~b}$ shows the service-and-trade-adjusted series and payroll-method series for company and other funds for R\&D performance for chemical manufacturing firms, the category that includes pharmaceutical and medicine manufacturing. As shown, the estimates in the service-and-trade-adjusted series are nearly identical to the estimates in the payroll-method series prior to 1992. However, from 1992 to 1996 the service-and-trade-adjusted series becomes slightly higher than the payroll-method series. There are large differences between the adjusted series and the payroll-method series for the years 1996 to 2008. For instance, in 1999, the adjusted estimate was 20 billion dollars higher than the payroll-method estimate; in 2003, the adjusted series was 11 billion dollars higher than the payrollmethod series. The results demonstrate that the domestic composition of R\&D-performing firms in the chemical industry is undergoing a fundamental change during this period: the economic activity in the U.S. is shifting away from chemical manufacturing for R\&D-performing firms. This takes place even as their R\&D performance increases steadily. Within services and trade, wholesale trade is the industry that is most affected by this shifting to chemical manufacturing.

Figure $3 \mathrm{c}$ is included to show that the two categories we have described, computer and electronic product manufacturing and chemical manufacturing, make up most of the impact of the adjustment for manufacturing R\&D. Figure $3 c$ shows the service-and-trade-adjusted series and the payroll method for company and other funds for R\&D performance for the all other manufacturing industries. As shown, the two series are almost identical before 1998 and from 1998 forward the adjusted series is slightly higher than the unadjusted series. The firms in the other manufacturing industries are less R\&D intensive compared to firms in chemical product manufacturing and computer and electronic product manufacturing.

\section{Evidence of Factoryless Groods Production}

The trends from manufacturing to services are apparent for all firms in the LBD, not just for R\&Dperforming firms. Tables $4 \mathrm{a}$ and $4 \mathrm{~b}$ provide evidence of the shifting of firms from manufacturing to services industries. Table 4a shows that, out of the all firms that were assigned to the computer and electronic product manufacturing industry in 2002 by the payroll method, 7606 firms were still classified in the same industry in 2007. By 2007, 159 of these firms had shifted to a different industry (the sum of the four right most columns for computer and electronic products). Most of these firms shifted to trade, services, and management, rather than to a different goods-producing industry. This is consistent with firms shifting their manufacturing activities abroad or increasing their purchasing of contract manufacturing services from other firms within the U.S. or from abroad.

Table $4 \mathrm{~b}$ shows that the payroll in services, trade, and management of companies and enterprises industries for firms that were classified in computer and electronic product manufacturing in 
2002 increased by 70 percent from 2002 to 2007. Similarly, for firms that were classified in chemical manufacturing in 2002, payroll in trade, services, and management industries increased by 90 percent from 2002 to 2007. For computer and electronic product manufacturing the services industries experienced the largest increase in payroll, however, for chemical manufacturing, management of companies and enterprises industry experienced the largest payroll increase. Within other services, the scientific R\&D and related services and information services absorb a large share of the shift.

\section{Robustness of Results}

We have described the methodology and results for alternative ways to classify R\&D performance by industry. One is based on payroll shares and the other ways make adjustments to the payroll method to attempt to show the industry of the product produced by the firm. We create our series for years from 1986 to 2008.

\section{Comparison to 2008 BRDIS}

For this final year, 2008, we have an independent source of information on the product produced with the firm's R\&D. We compare our estimates to the estimates produced from the lines of business information reported in the 2008 BRDIS. The firm-reported line of business information was used by NSF to assign firms to NAICS industries for the 2008 R\&D expenditures. For the firms that reported performing R\&D in only one line of business, they were assigned to the NAICS industry corresponding to the line of business reported. However, for the few firms that reported performing R\&D in more than one line of business, they were assigned to the NAICS industry corresponding to the line of business with the largest share of R\&D expenditures. ${ }^{14}$

For each firm, we compare the 4-digit NAICS industry code that was reported in the BRDIS to the 4-digit NAICS industry code from the LBD data sets. We then sum across firms to obtain the number of firms and the estimates of industry R\&D expenditures. ${ }^{15}$ In table 3 the company-funded R\&D performance is presented for six major economic groups for 2008. Table 3 shows a comparison of the estimates of company-funded R\&D performance based on the broad adjustment, more targeted adjustment, and the line of business information reported in the 2008 BRDIS.

For chemical manufacturing, our targeted adjustment and our trade-and-services adjustment result in similar shares of R\&D for chemical product manufacturing, $19.1 \%$ and $19.5 \%$ respectively. However, based on the line of business reported in the 2008 BRDIS, chemical product manufacturing accounted for $25.8 \%$ of company-funded R\&D. These differences translate to company-funded R\&D performance estimate based on the trade-and-services series that is about 8 billion dollars lower than

\footnotetext{
${ }^{14}$ For instance, a firm may have two or three business lines in manufacturing, but they reported R\&D in only one business line. Usually, this business line is the industry with the largest payroll share among all the firm's business lines. This approach is parallel to the payroll method, where firms are assigned to NAICS industries with the largest payroll shares.

${ }^{15}$ There is a mapping between the business lines and NAICS industry codes. The data have already been assigned to NAICS industry codes based on the reported business lines.
} 
the company-funded R\&D performance estimate based on the line of business information for chemical manufacturing.

Our adjustment method depends on the existence of manufacturing establishments within the firm at some point in the period from 1986 to 2008 in the LBD. While their domestic payroll is in the trade and services industries, we expect that many of these are performing manufacturing activities outside the U.S. or contracting manufacturing activities to other firms in the U.S. and abroad. This is consistent with "factoryless" goods-producing firms. Another reason for the difference may be because of the timing issues related to the LBD. Sometimes not all the establishments of the firms are reported in the LBD in the current year because of mergers and acquisitions, leverage buyout and divestitures. ${ }^{16}$

For computer and electronic product manufacturing there is a larger gap between the two adjustment methods. The targeted adjustment results in a R\&D share of 16.9 percent, compared to 22.3 percent for the trade-and-services-adjusted series. The trade-and-services-adjusted expenditures for 2008 are very close to the expenditures classified in computer and electronic product manufacturing based on line of business, 22.3 percent versus 22.9 percent. This suggests a greater U.S. presence for manufacturing establishments in this industry, at least historically.

\section{Comparison to Company-funded R\&D Expenditures}

Figure 4 shows the comparison of NSF-published data for the manufacturing share of company and other funds for R\&D to our adjusted company and other funds. Our service-and-trade-adjusted estimates are higher than the NSF-published estimates. However, for years 2004-2007, the differences are very small. This is because the NSF adjusted the estimates by moving firms that were classified in wholesale trade, management of companies and enterprises, and the scientific R\&D and related services industries to manufacturing industries.

\section{Conclusion}

This paper develops a method for producing a consistent time series of R\&D expenditure data for R\&Dperforming industries. Using SIRD, BRDIS, and LBD micro-data sets, we merge the firm-level SIRD and BRDIS data sets to establishments in the LBD, recode establishments in the LBD from SIC to NAICS, adjust firms industry codes in the SIRD, and allocate the firms' R\&D expenditures to establishments that are more likely to perform R\&D.

Compared to the hierarchical payroll method, which uses information about the domestic component of firm activity, our trade-and-services-adjusted series reduces the amount of R\&D expenditures allocated to wholesale trade by more than 30 percent. In addition, it increases the amount of R\&D expenditures allocated to manufacturing industries by 5 percent. The manufacturing industries with the largest increases are computer and electronic product manufacturing (60 percent) and chemical manufacturing (25 percent).

\footnotetext{
${ }^{16}$ Foster and Grim (2010).
} 
In addition to the development of a more consistent time series for key U.S. R\&D-performing industries, our results also show the outlines of a structural shift within firms that sell manufactured goods with R\&D content. Increasingly, the U.S. economic activity of these firms is moving away from manufacturing and toward services. For R\&D-performing firms, the transition of the Federal Statistical System from SIC to NAICS played a substantial role in revealing this shift.

Our results have significance for the analysis of the impact of R\&D on firm productivity and industry productivity. This is because previous studies have used R\&D expenditures data that had R\&D allocated to the wholesale trade and the services industries, when the expenditures were instead directed towards goods production. The consistent time series based on the products produced provide a better understanding of the relationship of R\&D activity as an input in the production of goods and services within firms.

\section{References}

Acemoglu, Daron, Ufuk Akcigit, Nicholas Bloom, and William Kerr, "Innovation, Reallocation, and Growth", Working Paper (2010).

Adams, James D and Suzanne Peck, "A Guide to R\&D Data at the Center for Economic Studies U.S. Bureau of the Census, "Working Papers 94-9, Center for Economic Studies, U.S. Census Bureau (1994).

Adams, James D and Adam B. Jaffe, The Span of the Effect of R\&D in the Firm and Industry", "Working 94-7, Center for Economic Studies, U.S. Census Bureau (1994).

Adams, James D \& Adam B. Jaffe, "Bounding the Effects of R\&D: An Investigation Using Matched Establishment-Firm Data, "NBER Working Papers 5544, National Bureau of Economic Research, Inc. (1996).

Akcigit, Ufuk and William R. Kerr,"Growth through Heterogeneous Innovations" (October 27, 2010). PIER Working Paper No. 10-035.

Bayard, Kimberly N. and Shawn D, Klimek, "Creating a Historical Bridge for Manufacturing Between the Standard Industrial Classification System and the North American Classification System," presented at the Joint Statistical Meetings in San Francisco, August 2003.

Bayard, Kimberly N. and David Byrne and Dominic Smith. "The Scope of U.S. Factoryless Manufacturing, Paper prepared for Upjohn conference on Measuring the Effects of Globalization, February 28, 2013. 
Bureau of Economic Analysis, "Preview of the 2013 Comprehensive Revision of the National Income and Product Accounts: Changes in Definitions and Presentations," Survey of Current Business, March 2013, 13-39.

Economic Classification Policy Committee, "Issue Paper No. 1. Conceptual Issues," Federal Register, March 31, 1993.

Foster, Lucia S. and Cheryl Grim, "Characteristics of the Top R\&D Performing Firms in the U.S.: Evidence from the Survey Of Industrial R\&D," Center for Economic Studies Working Paper 10-33, September 2010. Jarmin, Ron S. and Javier Miranda. "The Longitudinal Business Database." Center for Economic Studies Discussion Paper CES-WP-02-17., 2002,

Klimek, Shawn and David Merrell, "On Reclassifying Industries from Standard Industrial Classification System to the North American Industrial Classification System", The Second International Conference on Establishment Surveys Proceedings, June 2000.

Lichtenberg, F. and D. Siegel, "The Impact of R\&D Investment on Productivity - New Evidence Using R\&D - LRD Data," Economic Inquiry 29 (2), 1991, 203-228.

Parker, Robert. "Restoring the Enterprise Statistics Program for the 2012 Economic Census." 2012.

Office of Personnel Management, 2002 North American Industry Classification System (NAICS).

Ribarsky, Jennifer "Factoryless" Manufacturers: Classification and Implementation Challenges", Paper Prepared for the 32nd Conference on Income and Wealth, August, 2012, Boston, Massachusetts.

Shackelford, Brandon "Industry Classification of Companies in NSF R\&D Surveys: Guiding Principles and History." Unpublished paper to the National Science Foundation, Division of Science Resources Statistics. Arlington, VA. May 28, 2008.

United Nations, Economic Commission for Europe, and Conference of European Statisticians, "Guide to measuring global production," Prepared by the Task Force on Global Production, 8 January, 2014.

U.S. Bureau of Economic Analysis (BEA), U.S. Direct Investment Abroad: 2009 Revised Benchmark Data (Washington, DC: BEA, April 2013): M-12-M-16. 
Figure 1a: Year-to-year change in funds for R\&D performance relative to 1972 by firms in services-producing industries, 1972-2008

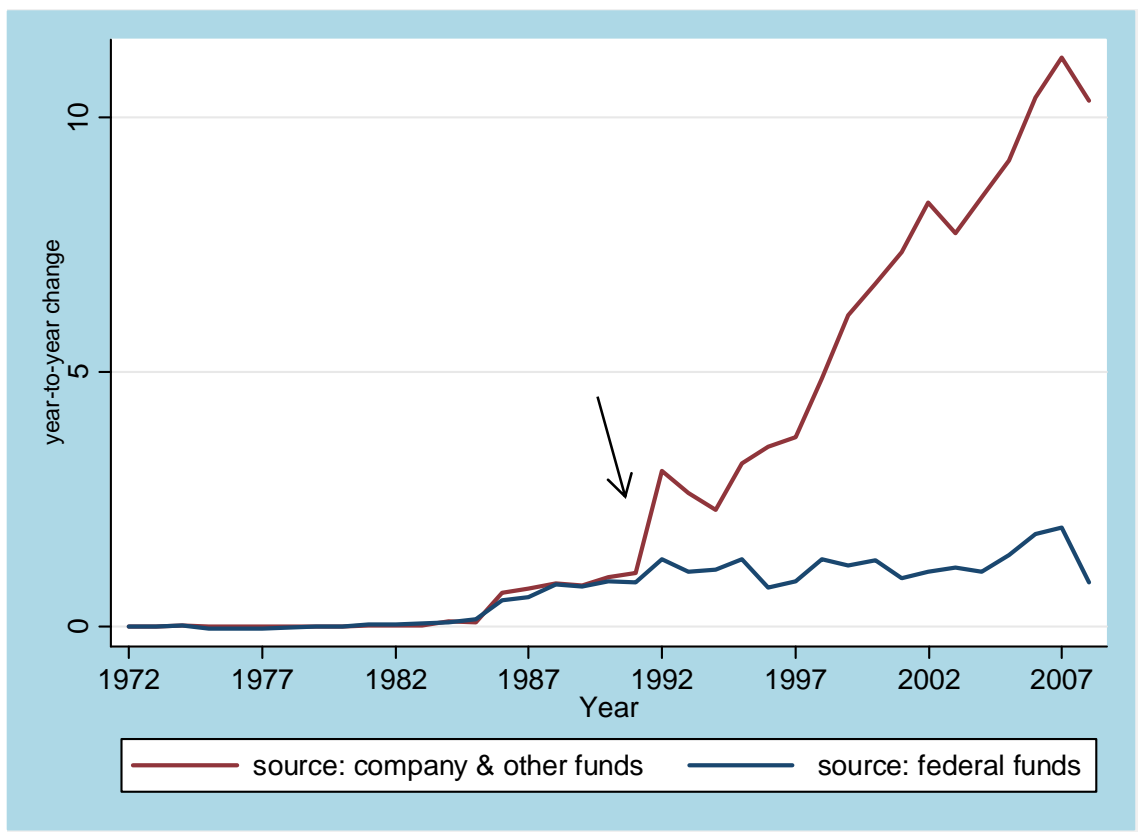

Source: SIRD data and authors' own calculations. Arrow shows end of "freezing" of firms in manufacturing.

Figure 1b: Year-to-year change in funds for R\&D performance relative to 1972 for firms in manufacturing industry group, 1972-2008

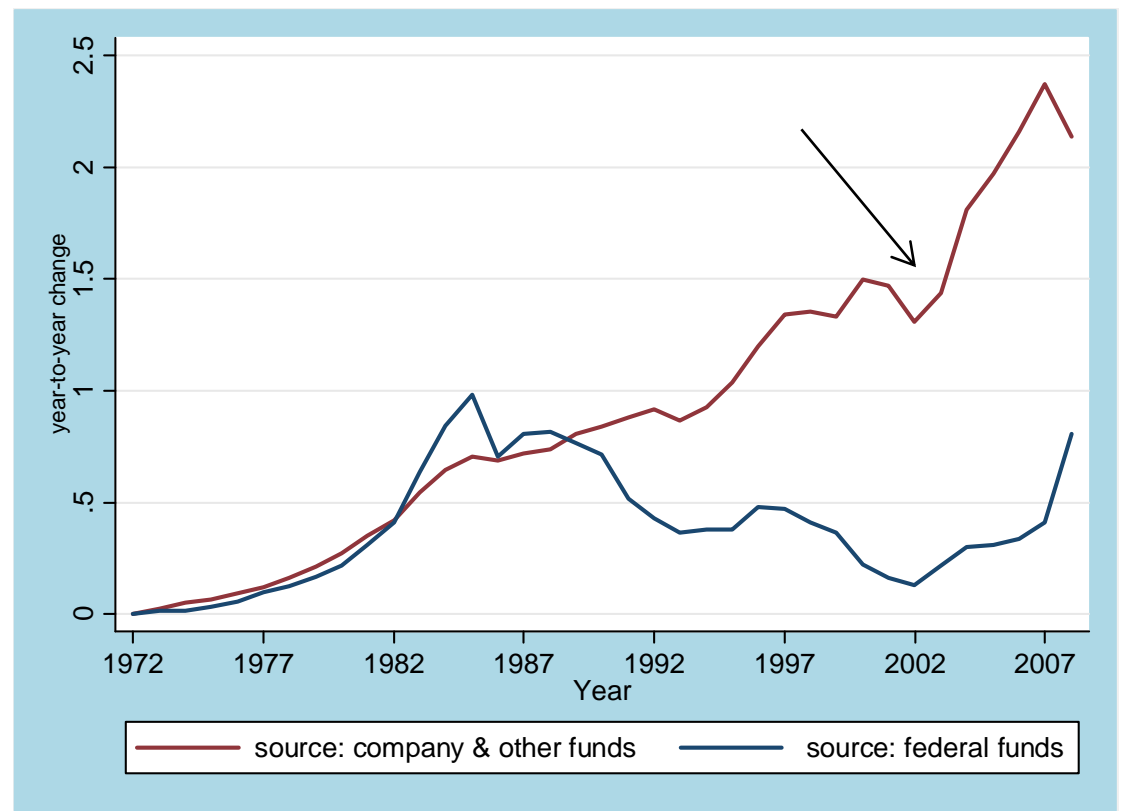

Source: SIRD data and authors' own calculations . Arrow shows wholesale trade adjustment. 
Figure 1c: Year-to-year change in company and other funds R\&D performance relative to 1972 by firms in the wholesale trade industry, 1972-2008

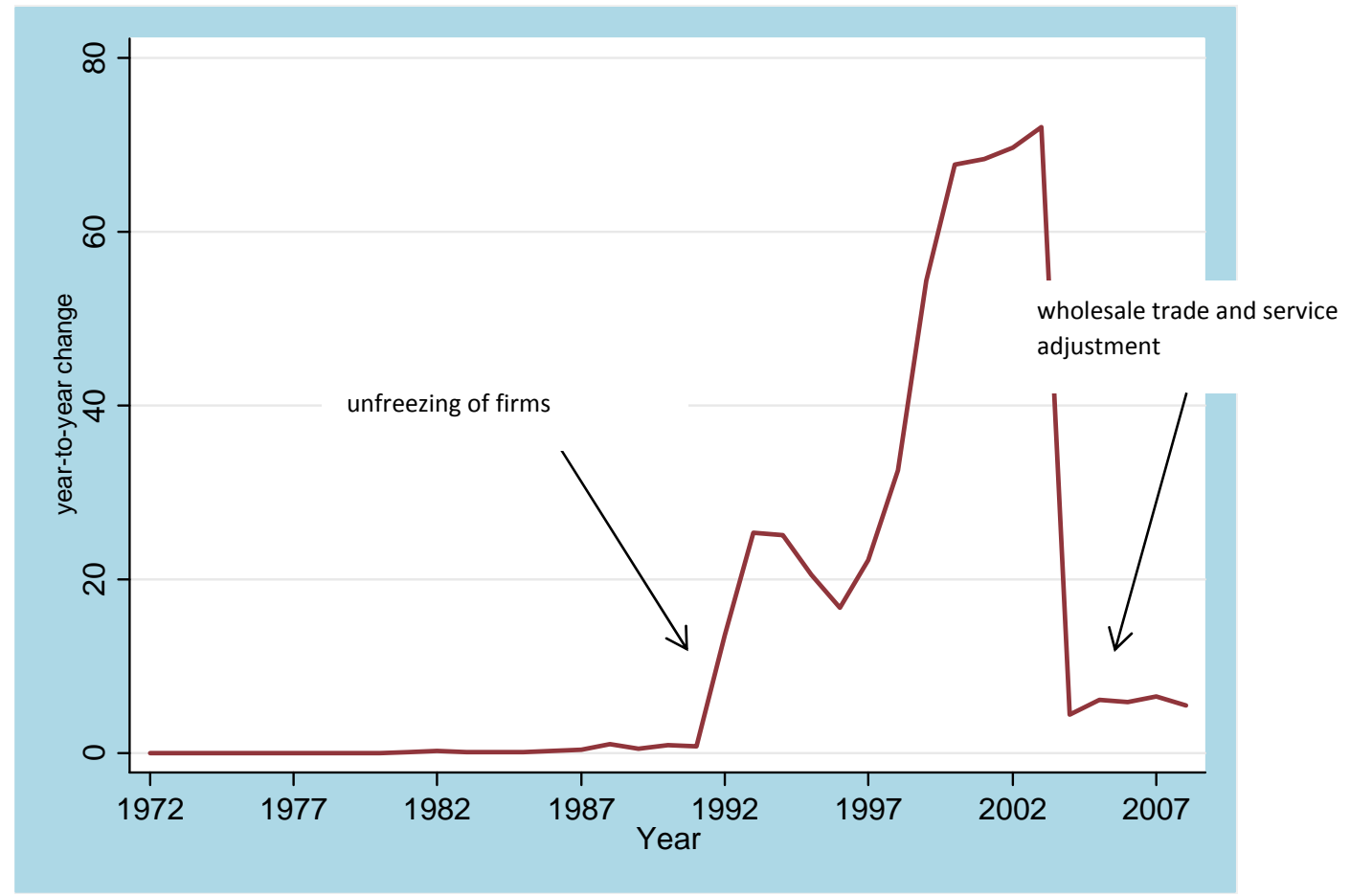

Source: SIRD data and authors' own calculations.

Figure 2a: Company and other funds for R\&D performance by firms in manufacturing industries

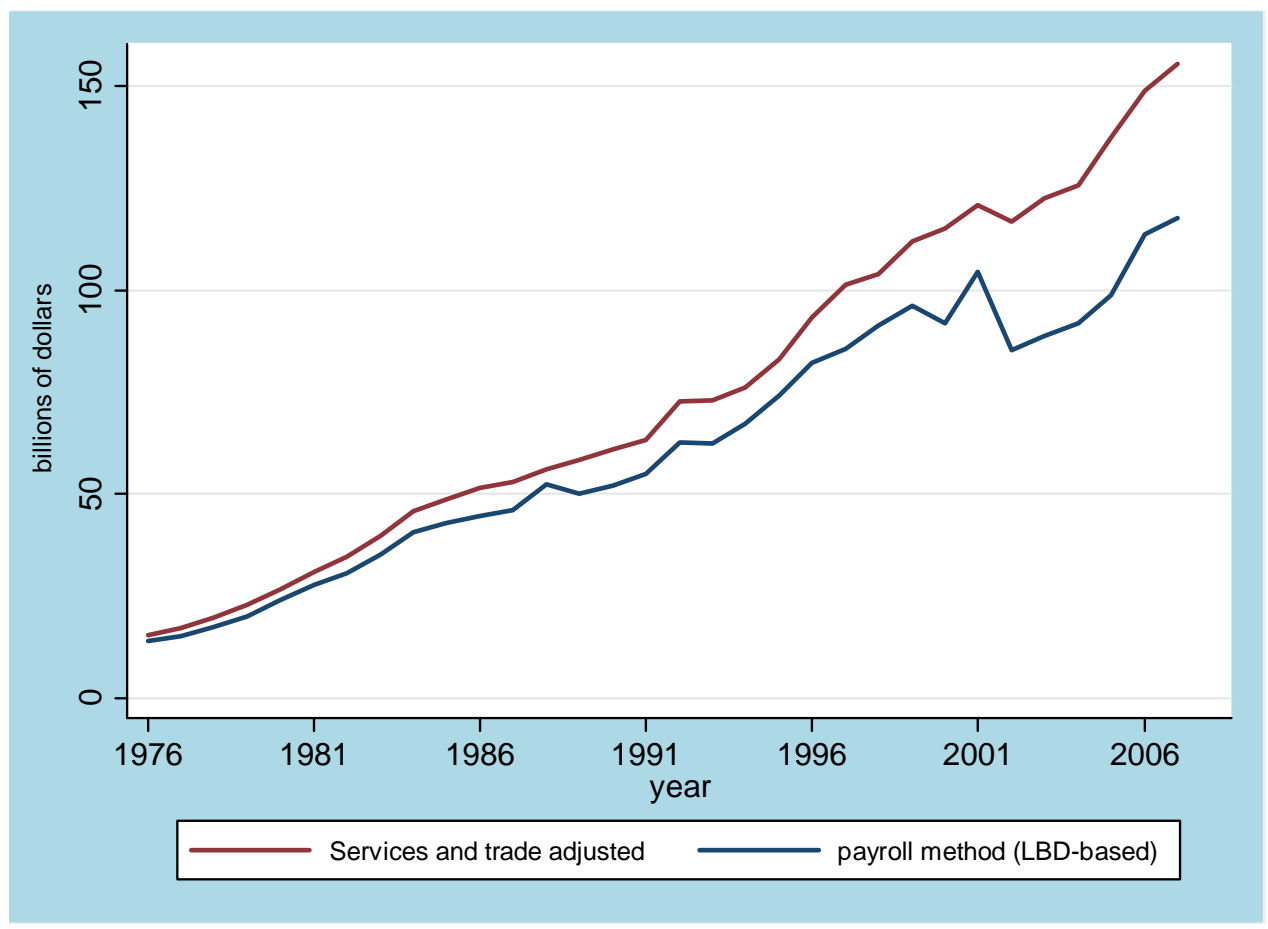

Source: SIRD data and authors' own calculations. 
Figure $2 b$ : Federal funds for R\&D performance by firms in manufacturing industries

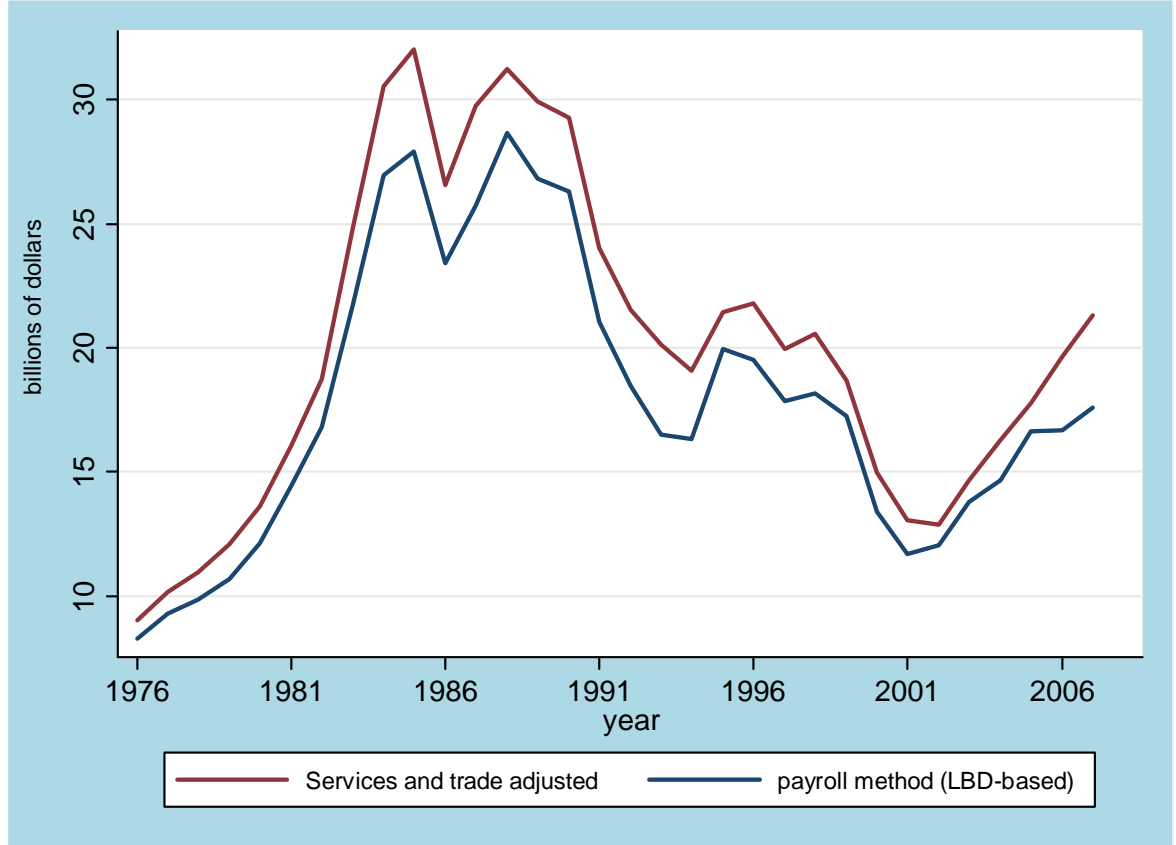

Source: SIRD and BRDIS. Authors' own calculations.

Figure 3a: Company and other funds for R\&D performance by firms in computer and electronic product manufacturing

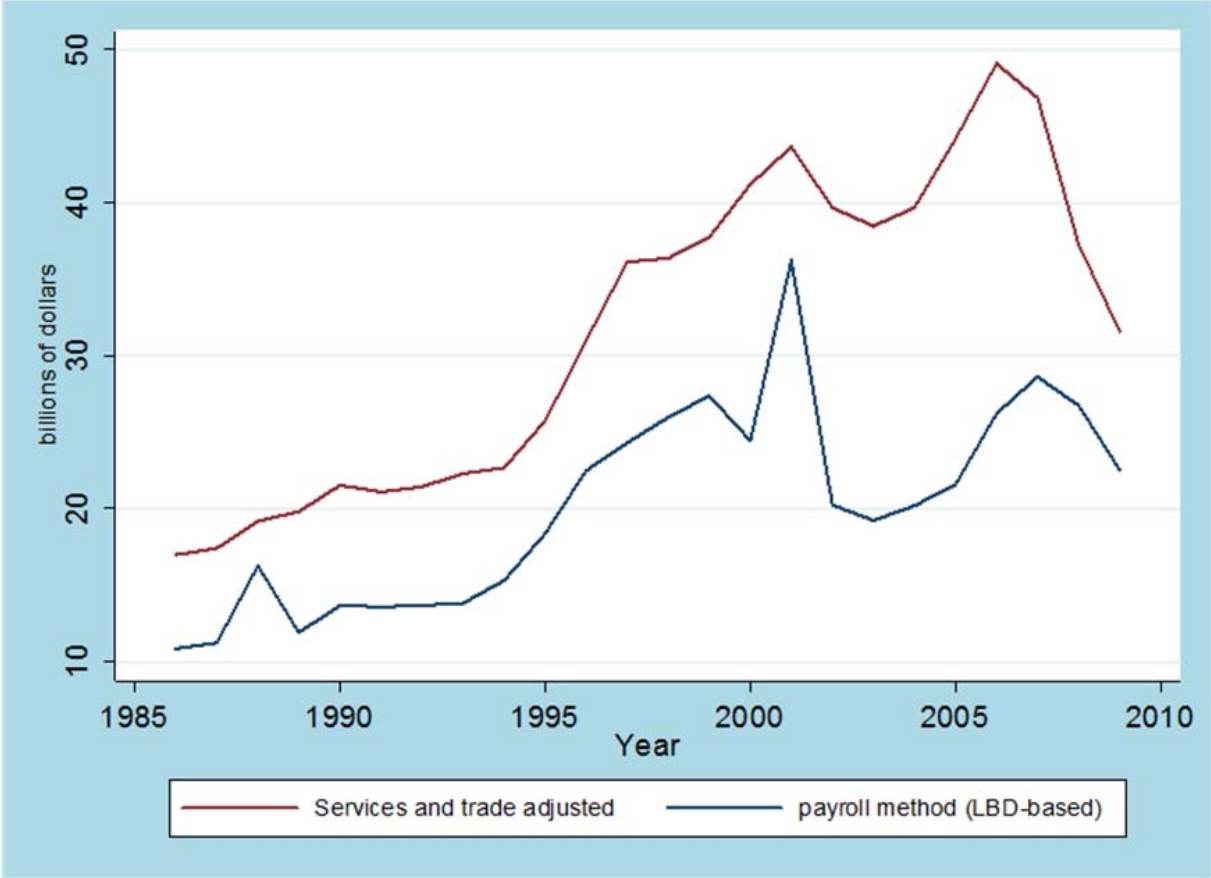

Source: SIRD and BRDIS. Authors' own calculations. 
Figure 3b: Company and other funds for R\&D performance by firms in chemical manufacturing

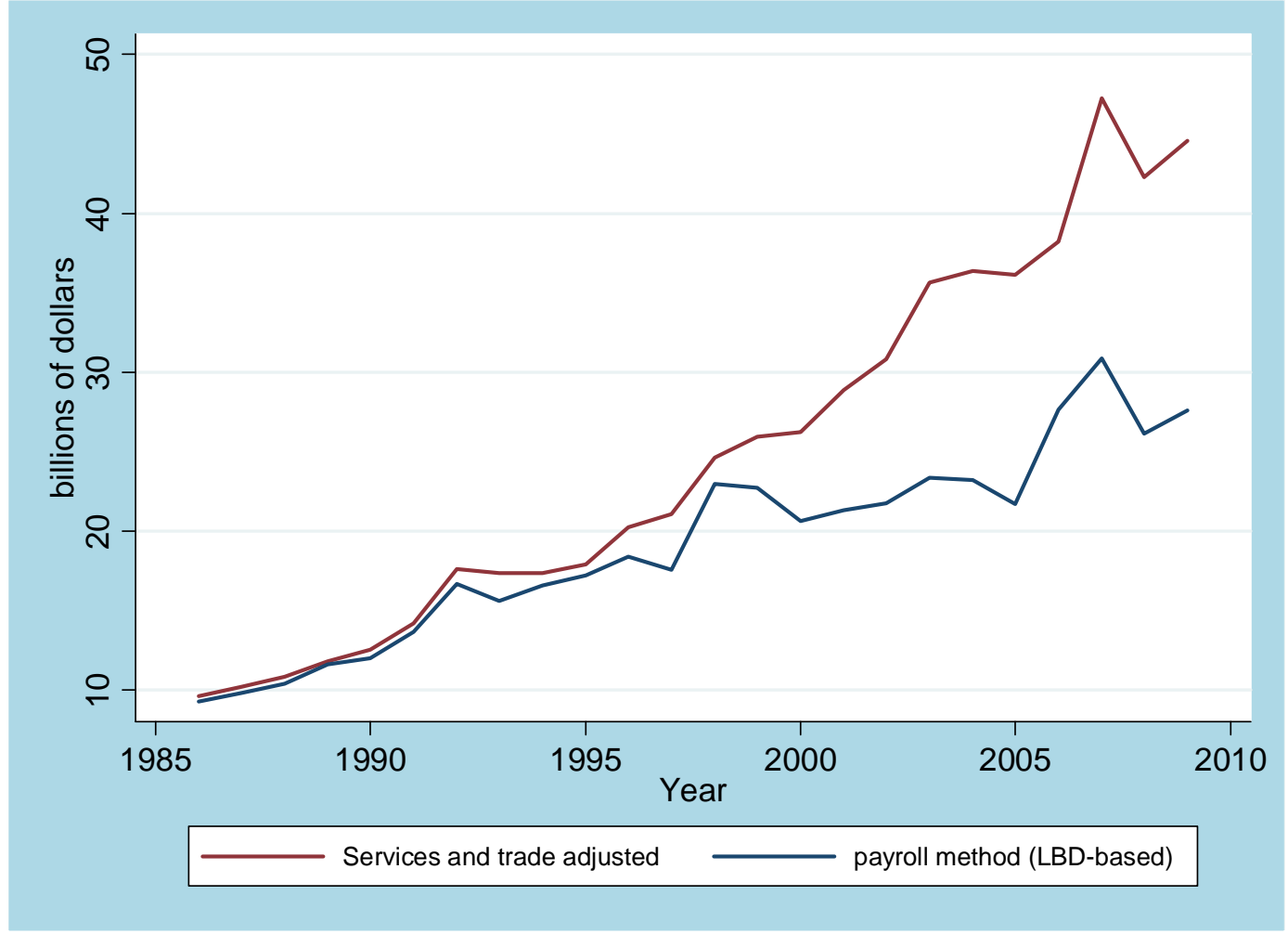

Source: SIRD and BRDIS. Authors' own calculations.

Figure 3c: Company and other funds for R\&D performance by firms in manufacturing industries except computer and electronic product manufacturing and chemical manufacturing

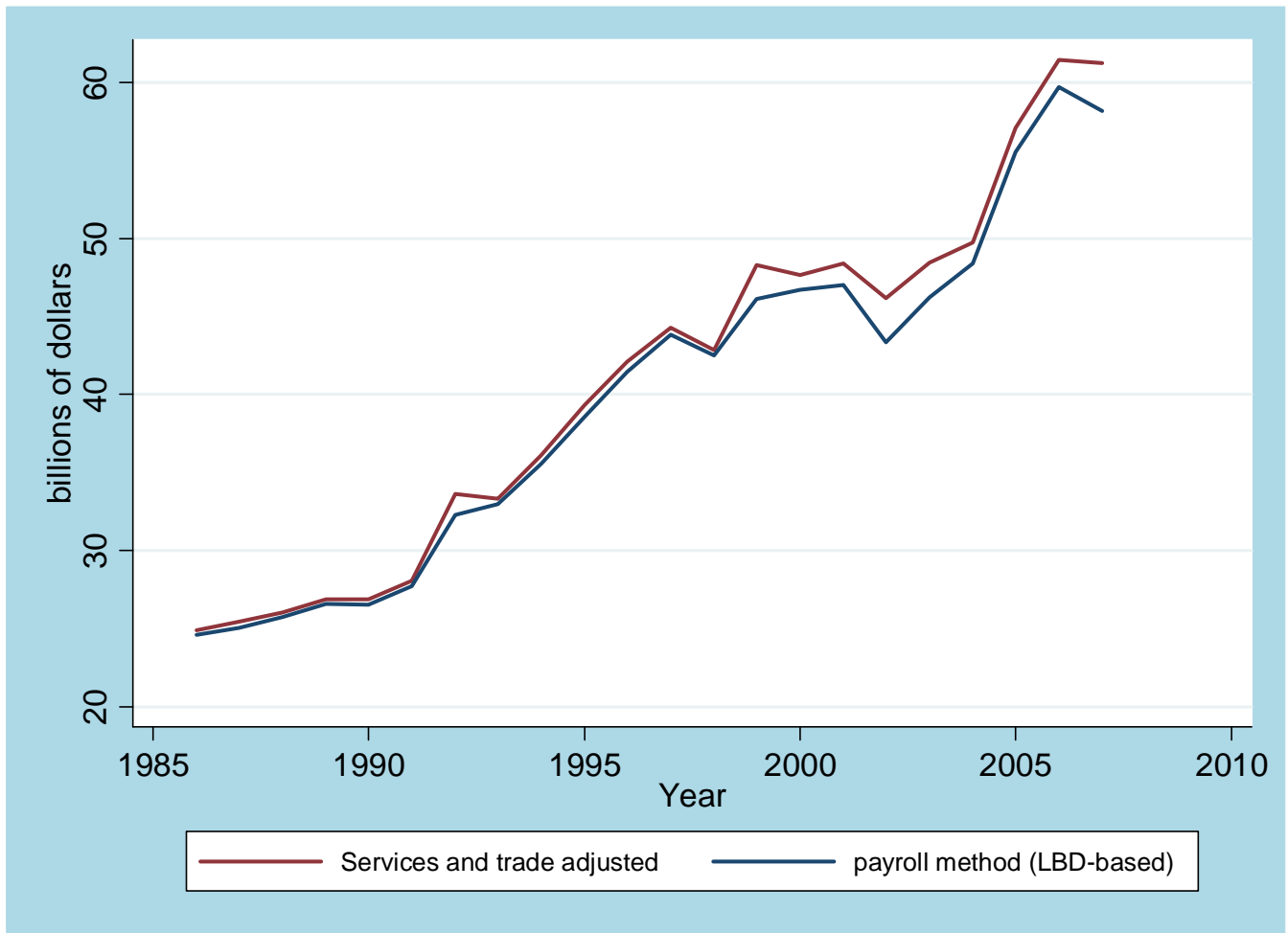

Source: SIRD and BRDIS. Authors' own calculations. 
Figure 4: Manufacturing industries' share of R\&D expenditures, 1985-2007

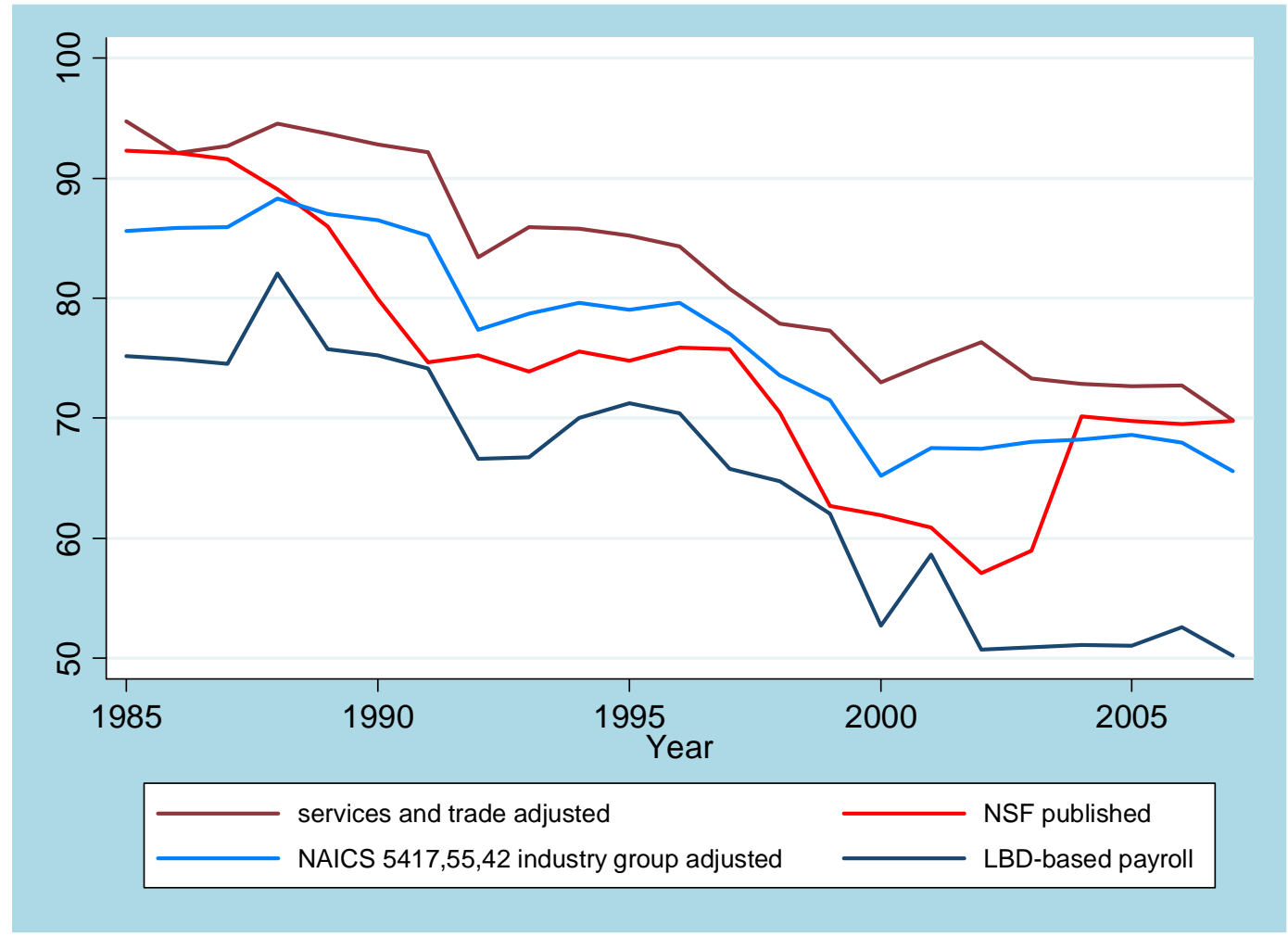

Source: SIRD and BRDIS. Authors' own calculations.

Note: LBD-based payroll is the "payroll method (LBD-based)" in the other figures. 
Table 2a: The Impact of Service and Trade Adjustment on Firms in Services and Trade Industries

\begin{tabular}{|c|c|c|c|c|}
\hline \multirow{2}{*}{ Year } & \multicolumn{2}{|c|}{ Payroll method (LBD-based) } & \multicolumn{2}{|c|}{ Percent moved to manufacturing industries } \\
\hline & Number of firms & $\begin{array}{c}\text { Nonfederal R\&D expenditures } \\
\text { (billions of dollars) }\end{array}$ & Number of firms & Nonfederal R\&D expenditures \\
\hline 1986 & 196 & 7.6 & $51 \%$ & $89 \%$ \\
\hline 1987 & 202 & 8.0 & $48 \%$ & $88 \%$ \\
\hline 1988 & 197 & 4.5 & $50 \%$ & $81 \%$ \\
\hline 1989 & 181 & 9.4 & $47 \%$ & $89 \%$ \\
\hline 1990 & 182 & 10.0 & $46 \%$ & $88 \%$ \\
\hline 1991 & 185 & 9.9 & $39 \%$ & $85 \%$ \\
\hline 1992 & 371 & 19.8 & $35 \%$ & $51 \%$ \\
\hline 1993 & 482 & 17.3 & $35 \%$ & $61 \%$ \\
\hline 1994 & 372 & 12.9 & $37 \%$ & $67 \%$ \\
\hline 1995 & 428 & 14.2 & $27 \%$ & $62 \%$ \\
\hline 1996 & 489 & 17.9 & $18 \%$ & $62 \%$ \\
\hline 1997 & 498 & 24.9 & $16 \%$ & $63 \%$ \\
\hline 1998 & 386 & 26.3 & $16 \%$ & $47 \%$ \\
\hline 1999 & 488 & 26.5 & $13 \%$ & $60 \%$ \\
\hline 2000 & 528 & 41.9 & $17 \%$ & $56 \%$ \\
\hline 2001 & 548 & 30.4 & $16 \%$ & $54 \%$ \\
\hline 2002 & 734 & 44.5 & $22 \%$ & $70 \%$ \\
\hline 2003 & 989 & 50.0 & $18 \%$ & $68 \%$ \\
\hline 2004 & 1154 & 53.1 & $19 \%$ & $64 \%$ \\
\hline 2005 & 1501 & 59.8 & $16 \%$ & $64 \%$ \\
\hline 2006 & 1510 & 57.1 & $15 \%$ & $62 \%$ \\
\hline 2007 & 1461 & 66.9 & $16 \%$ & $56 \%$ \\
\hline 2008 & 1337 & 53.3 & $15 \%$ & $56 \%$ \\
\hline $\begin{array}{c}\text { Average } \\
1985-2008\end{array}$ & 627 & 29.0 & $28 \%$ & $67 \%$ \\
\hline
\end{tabular}

Source: Survey of Industry R\&D and Business R\&D and Innovation Survey. Authors' own calculations. 
Table 2b: Reassignment of Firms and Nonfederal R\&D Expenditures for Services and Trade Industries to Manufacturing Industries

\begin{tabular}{|c|c|c|c|c|c|c|c|c|}
\hline \multirow{2}{*}{ Year } & \multicolumn{2}{|c|}{ All manufacturing industries } & \multicolumn{2}{|c|}{$\begin{array}{l}\text { Computer and electronic } \\
\text { product manufacturing }\end{array}$} & \multicolumn{2}{|c|}{ Chemical manufacturing } & \multicolumn{2}{|c|}{ Other manufacturing } \\
\hline & $\begin{array}{l}\text { Number } \\
\text { of firms }\end{array}$ & $\begin{array}{l}\text { R\&D expenditures } \\
\text { (billions of dollars) }\end{array}$ & $\begin{array}{l}\text { Share of } \\
\text { firms }\end{array}$ & $\begin{array}{l}\text { Share of R\&D } \\
\text { expenditures }\end{array}$ & $\begin{array}{l}\text { Share of } \\
\text { firms }\end{array}$ & $\begin{array}{l}\text { Share of R\&D } \\
\text { expenditures }\end{array}$ & $\begin{array}{l}\text { Share of } \\
\text { firms }\end{array}$ & $\begin{array}{l}\text { Share of R\&D } \\
\text { expenditures }\end{array}$ \\
\hline 1986 & 99 & 6.8 & $29 \%$ & $90 \%$ & $14 \%$ & $5 \%$ & $57 \%$ & $5 \%$ \\
\hline 1987 & 97 & 7.0 & $24 \%$ & $89 \%$ & $12 \%$ & $5 \%$ & $64 \%$ & $6 \%$ \\
\hline 1988 & 99 & 3.6 & $26 \%$ & $81 \%$ & $14 \%$ & $11 \%$ & $60 \%$ & $8 \%$ \\
\hline 1989 & 85 & 8.4 & $29 \%$ & $94 \%$ & $14 \%$ & $2 \%$ & $56 \%$ & $4 \%$ \\
\hline 1990 & 83 & 8.8 & $25 \%$ & $90 \%$ & $14 \%$ & $6 \%$ & $60 \%$ & $4 \%$ \\
\hline 1991 & 72 & 8.4 & $24 \%$ & $90 \%$ & $15 \%$ & $7 \%$ & $61 \%$ & $4 \%$ \\
\hline 1992 & 131 & 10.0 & $28 \%$ & $78 \%$ & $17 \%$ & $9 \%$ & $55 \%$ & $13 \%$ \\
\hline 1993 & 171 & 10.6 & $25 \%$ & $80 \%$ & $20 \%$ & $17 \%$ & $56 \%$ & $3 \%$ \\
\hline 1994 & 137 & 8.7 & $30 \%$ & $85 \%$ & $18 \%$ & $9 \%$ & $52 \%$ & $6 \%$ \\
\hline 1995 & 117 & 8.8 & $30 \%$ & $84 \%$ & $16 \%$ & $8 \%$ & $54 \%$ & $8 \%$ \\
\hline 1996 & 89 & 11.1 & $34 \%$ & $77 \%$ & $24 \%$ & $17 \%$ & $43 \%$ & $6 \%$ \\
\hline 1997 & 82 & 15.7 & $33 \%$ & $75 \%$ & $32 \%$ & $22 \%$ & $35 \%$ & $3 \%$ \\
\hline 1998 & 63 & 12.5 & $37 \%$ & $84 \%$ & $27 \%$ & $13 \%$ & $37 \%$ & $3 \%$ \\
\hline 1999 & 63 & 15.8 & $35 \%$ & $66 \%$ & $30 \%$ & $20 \%$ & $35 \%$ & $14 \%$ \\
\hline 2000 & 90 & 23.3 & $39 \%$ & $72 \%$ & $30 \%$ & $24 \%$ & $31 \%$ & $4 \%$ \\
\hline 2001 & 88 & 16.4 & $32 \%$ & $45 \%$ & $33 \%$ & $46 \%$ & $35 \%$ & $8 \%$ \\
\hline 2002 & 164 & 31.4 & $29 \%$ & $62 \%$ & $25 \%$ & $29 \%$ & $46 \%$ & $9 \%$ \\
\hline 2003 & 181 & 33.8 & $28 \%$ & $57 \%$ & $26 \%$ & $36 \%$ & $46 \%$ & $7 \%$ \\
\hline 2004 & 220 & 34.0 & $28 \%$ & $57 \%$ & $25 \%$ & $39 \%$ & $47 \%$ & $4 \%$ \\
\hline 2005 & 244 & 38.5 & $26 \%$ & $59 \%$ & $26 \%$ & $37 \%$ & $48 \%$ & $4 \%$ \\
\hline 2006 & 230 & 35.2 & $24 \%$ & $65 \%$ & $27 \%$ & $30 \%$ & $49 \%$ & $5 \%$ \\
\hline 2007 & 240 & 37.7 & $22 \%$ & $48 \%$ & $29 \%$ & $43 \%$ & $49 \%$ & $8 \%$ \\
\hline 2008 & 207 & 29.8 & $19 \%$ & $35 \%$ & $28 \%$ & $54 \%$ & $54 \%$ & $11 \%$ \\
\hline $\begin{array}{c}\text { Average } \\
1986-2008\end{array}$ & 133 & 18.1 & $29 \%$ & $72 \%$ & $22 \%$ & $21 \%$ & $49 \%$ & $6 \%$ \\
\hline
\end{tabular}

Source : Survey of Industry R\&D and Business R\&D and Innovation Survey. Authors' own calculations. 
Table 3: Number of Firms and R\&D Expenditures by Alternative Methodologies, 2008

\begin{tabular}{|c|c|c|c|c|c|c|}
\hline \multirow{2}{*}{ Industry group } & \multicolumn{2}{|c|}{ Targeted Adjustment } & \multicolumn{2}{|c|}{$\begin{array}{l}\text { Broad-based } \\
\text { Adjustment }\end{array}$} & \multicolumn{2}{|c|}{ Line of Business-Based } \\
\hline & Firms & R\&D share & Firms & R\&D share & Firms & R\&D share \\
\hline All industries & 8830 & $100.0 \%$ & 8830 & $100.0 \%$ & 8830 & $100.0 \%$ \\
\hline $\begin{array}{l}\text { Food and beverage; textile and } \\
\text { textile product mills; apparel, } \\
\text { leather, and allied product; Wood } \\
\text { product; paper; printing and related } \\
\text { support activities; petroleum and } \\
\text { coal products }\end{array}$ & 822 & $3.4 \%$ & 860 & $4.1 \%$ & 785 & $3.0 \%$ \\
\hline Chemical product & 729 & $19.1 \%$ & 750 & $19.5 \%$ & 934 & $24.8 \%$ \\
\hline $\begin{array}{l}\text { Plastic and rubber products; } \\
\text { nonmetallic mineral product; } \\
\text { Primary metal; fabricated metal } \\
\text { product }\end{array}$ & 1852 & $7.0 \%$ & 1915 & $7.8 \%$ & 1926 & $7.2 \%$ \\
\hline Computer and el ectronic product & 966 & $16.9 \%$ & 1001 & $22.3 \%$ & 1130 & $22.9 \%$ \\
\hline $\begin{array}{l}\text { Electrical equipment, appliance, and } \\
\text { component; transportation } \\
\text { equipment; Machinery; furniture and } \\
\text { related product; miscellaneous }\end{array}$ & 1360 & $12.9 \%$ & 1384 & $13.3 \%$ & 1599 & $11.6 \%$ \\
\hline Nonmanufacturing & 3101 & $40.7 \%$ & 2920 & $33.0 \%$ & 2456 & $30.5 \%$ \\
\hline
\end{tabular}

Source : Survey of Industry R\&D. Authors' own calculations.

Note: The more-targeted adjustment was made to firms assigned to wholesale trade, scientific research and development and related services, and management of companies and enterprises. The broadbased adjustment is the same as our services-and-trade adjustment. The line of business-based is based on the line of business information reported by firms in the BRDIS. 
Table 4a: Selected Firms Industry Classification in 2002 and in 2007

\begin{tabular}{|c|c|c|c|c|c|}
\hline Industry classification in 2002 & \multicolumn{5}{|c|}{ Industry classification in 2007} \\
\hline Industry group & $\begin{array}{c}\text { Same industry } \\
\text { as in } 2002\end{array}$ & Trade & Services & Management & $\begin{array}{l}\text { Other goods- } \\
\text { producing } \\
\text { industries }\end{array}$ \\
\hline All manufacturing firms & 180882 & 442 & 242 & 293 & 599 \\
\hline $\begin{array}{l}\text { Food and beverage; textile and } \\
\text { textile product mills; apparel, } \\
\text { leather, and allied product }\end{array}$ & 24282 & 100 & 40 & 54 & 49 \\
\hline $\begin{array}{l}\text { Wood product; paper; printing } \\
\text { and related support activities; } \\
\text { petroleum and coal products }\end{array}$ & 33079 & 48 & 35 & 29 & 47 \\
\hline Chemical product & 5337 & 38 & 18 & 46 & 46 \\
\hline $\begin{array}{l}\text { Plastic and rubber products; } \\
\text { nonmetallic mineral product }\end{array}$ & 14016 & 54 & 20 & 26 & 82 \\
\hline Computer and electronic product & 7606 & 46 & 35 & 28 & 50 \\
\hline $\begin{array}{l}\text { Electrical equipment, appliance, } \\
\text { and component; transportation } \\
\text { equipment }\end{array}$ & 9205 & 24 & 27 & 21 & 68 \\
\hline $\begin{array}{l}\text { Primary metal; fabricated metal } \\
\text { product; machinery; furniture and } \\
\text { related product; miscellaneous }\end{array}$ & 87357 & 132 & 132 & 89 & 257 \\
\hline
\end{tabular}

Source: Longitudinal Business Database. Authors' own calculations. 
Table 4b: Percent Increase in Payroll by Industry for Selected Firms in Manufacturing from 2002 to 2007

\begin{tabular}{|c|c|c|c|c|}
\hline \multirow{2}{*}{$\begin{array}{l}\text { Industry classification in } 2002 \\
\text { Industry group }\end{array}$} & \multicolumn{4}{|c|}{ Industry classification in 2007} \\
\hline & Trade & Services & Management & $\begin{array}{l}\text { Trade, Services, } \\
\text { and Management } \\
\text { Combined }\end{array}$ \\
\hline All manufacturing firms & $11 \%$ & $20 \%$ & $28 \%$ & $59 \%$ \\
\hline $\begin{array}{l}\text { Food and beverage; textile and } \\
\text { textile product mills; apparel, } \\
\text { leather, and allied product }\end{array}$ & $28 \%$ & $21 \%$ & $49 \%$ & $98 \%$ \\
\hline $\begin{array}{l}\text { Wood product; paper; printing } \\
\text { and related support activities; } \\
\text { petroleum and coal products }\end{array}$ & $6 \%$ & $1 \%$ & $40 \%$ & $47 \%$ \\
\hline Chemical product & $18 \%$ & $10 \%$ & $61 \%$ & $90 \%$ \\
\hline $\begin{array}{l}\text { Plastic and rubber products; } \\
\text { nonmetallic mineral product }\end{array}$ & $13 \%$ & $5 \%$ & $18 \%$ & $36 \%$ \\
\hline Computer and electronic product & $12 \%$ & $41 \%$ & $18 \%$ & $70 \%$ \\
\hline $\begin{array}{l}\text { Electrical equipment, appliance, } \\
\text { and component; transportation } \\
\text { equipment }\end{array}$ & $7 \%$ & $47 \%$ & $14 \%$ & $69 \%$ \\
\hline $\begin{array}{l}\text { Primary metal; fabricated metal } \\
\text { product; machinery; furniture and } \\
\text { related product; miscellaneous }\end{array}$ & $10 \%$ & $6 \%$ & $20 \%$ & $34 \%$ \\
\hline
\end{tabular}

Source: Longitudinal Business Database. Authors' own calculations. 